\title{
Perceptions of Russia in the Global World
}

Does Russian Education Policy Work?

Darya B. Kazarinova, Vasilya B. Taisheva

\begin{abstract}
Interaction and long-term strategies are essential in today's globalized world, yet both Russia's foreign policy and its relations with its Western partners are deteriorating. The Russian government frequently sends out controversial messages: from sovereignty, its own agenda, and "a turn to the East," to coherent integration with the global, or Western, agenda. This is especially true when it comes to education. Russians are highly educated; thus, education is automatically perceived as a soft power tool. However, in reality, major obstacles can emerge. The paper analyzes perceptions and attitudes of foreign students towards
\end{abstract}

Darya B. Kazarinova, $\mathrm{PhD}$ in Political Science

Department of Comparative Politics, Faculty of Humanities and Social Sciences

RUDN University, Russia

Associate Professor

Researcher ID A-5085-2017

Scopus Author ID 57195478048

E-mail: kazarinova-db@rudn.ru

Address: 6 Miklukho-Maklaya Str., Moscow 117198, Russia

Vasilya B. Taisheva

Department of Comparative Politics, Faculty of Humanities and Social Sciences

RUDN University, Russia

Postgraduate

Researcher ID: G-8648-2019

ORCID: 0000-0002-0459-7380

E-mail: taisheva-vv@rudn.ru

Address: 6 Miklukho-Maklaya Str., Moscow 117198, Russia

The article is supported by the Russian Foundation of Basic Research, Project 19-011-00825.

DOI: 10.31278/1810-6374-2019-17-4-20-52 
Russia: its image, political system, and role in the contemporary world. A survey conducted in 2017 (online and offline, half-closed anonymous questionnaire N100) involved foreign students, some of whom studied at Russian higher education institutions and some who did not. The students were asked about how they perceived Russia's role in the modern world, its soft power resources, political regime, and values. The research revealed a clear difference in the perception of those factors. It also showed that educational migration sometimes provides unexpected results that can contradict the aims of Russian education policy.

Keywords: Russia, higher education, migration, image, soft power, youth, students, perceptions, attitudes, associations, counter-power, alternative model, values, regime

\section{WHEN SOFT POWER IS GONE}

There are a number of reasons for the ongoing reformatting of the world order, including growing uncertainty, a decline in the role of soft power strategies, and a simultaneous comeback of Realpolitik mechanisms. Of the factors behind the instability of the world system, the following are worth mentioning: the polarization of interests and aims of the main global policy actors, growing external and internal contradictions in the European Union and the United States, the increasing role of non-Western countries in the world, the migration crisis, secession processes, and growing populism in Europe (Pantin and Lapkin, 2018).

Professor Richard Sakwa of the University of Kent maintains that the modern Cold War, or "clashes of world orders," began with the end of the Cold Peace in 2014 (Sakwa, 2019). The current confrontation is more civilizational and axiological than ideological: "fragmented ideas and values enter into dispute," and identities acquire great importance, thus initiating this standoff.

In short, in the context of civilizational and ideological confrontation, soft power factors play an important role, along with diplomacy, culture, and education. 


\section{RUSSIA'S IMAGE}

One such factor is the way an individual country is viewed in the world. It is considered an important strategic resource of international influence that ensures the country's competitive edge and prestige on the world stage, and effective integration with the global market and political system. A competently shaped image of the country guarantees support from the international community in the process of addressing various security issues, as well as economic and political ones of international importance. A good image also makes a country more attractive to foreign investors, skilled specialists, and tourists. This task is becoming particularly hard to cope with amid the United States' outspoken anti-Russian rhetoric and containment strategy, which it is dictating to the European Union (Atlantic Council Annual Report, 2018-2019).

In a situation like this, one of Russia's emerging priorities is shaping its internal and external identity, as well as crafting its related image in the process of modernizing society and charting official foreign policy. The way Russia is seen abroad is mostly negative and based on such stereotypes as economic backwardness, brute military force, and authoritarianism (Konstantinova and Martynov, 2008). Also, the image of modern Russia rests by and large upon outdated images and ideas propagated by modern mass culture and the media. At the same time, Russia's rich cultural and historical heritage and scientific achievements are reason enough to postulate that Russia's soft power is one of the greatest in the world (Zubov, 2011). The existing ideas of modern Russia and its place in the world, on the one hand, and the awareness of Russia's cultural and historical contribution to world civilization, on the other, contradict each other in the process of piecing together the country's integral image. In their coverage of the main ideas, values, and concepts of Russian civilization, the Russian mass media often fail to place the emphases accurately enough.

In shaping a country's image, an extremely important role is played by the humanitarian vector of foreign policy, in particular, cultural interaction and cooperation in the field of education. Educational migration is a means of exercising economic, political, and cultural 
influence (Astakhov, 2014). Educational migration has enormous prospects for the countries of origin and for the host states, and also promotes a positive dialogue. Additionally, education eases ideological and cultural contradictions and tensions that emerge in the context of the modern upsurge in migration flows and, as a result, of clashes between different civilizational systems.

\section{THE POWER OF EDUCATION}

In the context of its foreign policy, Russia considers the development of education and, in particular, its humanitarian aspect, as one of its top priority guidelines, as a number of legal acts clearly indicate. The National Education Doctrine to 2025 proclaims the restoration of Russia's status as a world power in education, culture, science, and engineering, and lists the economy as a strategic goal (Lexed.ru. 2000). The idea of enhancing Russia's role in the world humanitarian space was outlined in greater detail in Russia's Foreign Policy Concept of 2016, which, among other things, stressed such aspects as the promotion of the Russian language and Russian education and science around the world (Mid.ru, 2016).

Special emphasis has been placed on the role of Russian education globally and international cooperation in the field of education. The integration of Russia's education system with those of other countries on the basis of equality and mutually beneficial cooperation has received regulatory backing (273-fz.zf, 2012). This is why Russia joined the Bologna process at the Berlin meeting of the European countries' education ministers in 2003. Russian institutions of higher learning participate in academic mobility programs and implement joint educational programs with foreign educational establishments. The government program 5-100 sets the task of maximizing the competitiveness of a group of leading Russian universities on the global market of educational services and research programs. In particular, it encourages Russian universities to internationalize their activity and contests on international rating lists (Project 5-100). In official discourse, the internationalization of education is described as an unconditional and indisputable benefit that defies the criticism 
afoot inside the research and education community. That criticism targets the Bologna process and the managerial measures for involving Russian scientists in the international scientific space.

As far as the shaping of Russia's favorable image is concerned, education can serve as one of the priorities and promising factors. In the process of education students develop an outlook by obtaining knowledge about the surrounding world, gaining emotional experience, and acquiring critical thinking skills. From the standpoint of forming the country's image, education gives foreign students the chance to not only observe and obtain information, but also to participate proactively in the activities of the host society and become immersed in the social, linguistic, ideological, and cultural environment of the country where they receive education, become socialized, and adjust to alternative lifestyles. In other words, Russian education and educational migration serve as means of propagating Russia's values, culture, and realities and form the image of modern Russia and Russian society in the minds of young foreign students. Moreover, education is a resource that contributes to creating other countries' intellectual elites, which incorporate Russian university graduates and promote Russia's political and economic interests around the world. It also contributes to the emergence of long-term favorable conditions for the development of political, trading, economic, scientific, and technological cooperation between Russia and other countries (Russia. edu.ru, 2002). But how does this all work? What is the mechanism of acquiring and transforming ideological concepts in the process of educational migration, and how effective is it as a soft power tool? None of these questions have clear answers yet. Many dissertations examining the internationalization of education say the latter is not intensive enough.

Currently at the legislative level Russia has not set targets for using education as a way to construct the country's favorable image abroad, although such aims should obviously be on the agenda as long as a corresponding policy exists. However, none of these goals are properly formulated in legislative or regulatory acts or described in greater detail in education development concepts, educational standards, and 
programs, which, in turn, contain no elements of Russian studies. As a result, students' perception of the host country is spontaneous, and not the result of a well-charted strategy.

\section{RESEARCH AND METHODOLOGY}

The purpose of this study is to try to clear up the ideas that young foreigners have about Russia and identify the role of education and educational migration in the process of shaping the country's international image. The research relied on both theoretical and empirical methods to examine the phenomenon of migration and educational migration, as well as the issues of shaping the country's image.

In the theoretical research into educational migration, we used both systemic and transnational approaches that best highlight the sociocultural aspects of migration processes. The systemic approach focuses on the structure and relationships of individuals between themselves and social processes in the context of migration (Samofalova, 2015). In the context of the systemic approach one should emphasize the European theory of labor migration by P. White and R. Woods (1980), the theory of global migration systems by M. Kritz (1992), as well as the theory of the cyclical nature and interdependence of the migration process on other components of the social system by T. Feist (1997). Also, the transnational approach is based on the study of the processes of integrating and assimilating migrants into the host society in the context of globalization. According to Transnationalism: A New Analytic Framework for Understanding Migration (Schiller, Basch and Blanc, 1992), migration works as a mechanism for expanding the space of cultural interactions.

Many works by Russian authors are devoted to the image of the state, its formation, and development. The theoretical approaches to this issue were considered in their writings by A. Krotov, N. Zamyatina, Ye. Petrova, A. Panasyuk, and N. Arbatova. Also, while speaking of historical approaches to the study of such a phenomenon as a country's image, it is necessary to note the comprehensive concept of defining and promoting the image of Russia by Ye. Galumov, as well as metageography or figurative geography by D. Zamyatin. 
The problem of forming the image of any country in general and of Russia in particular is examined in works by such scholars as Ye. Shestopal, A. Graver, D. Leontiev, S. Golunov, E. Astakhov and others. Also, for the present study, of certain interest are works by Ye. Tarasov (2006), which are based on the methods of free associations, groups, and projective methods. The process and specifics of forming a country's image on the basis of identity and national self-determination are highlighted in the works by G. Weinstein, I. Semenenko, V. Lapkin, V. Pantin, S. Chugrov, and others.

A survey of foreign students conducted at the end of 2017 served as the empirical basis for this study. Questionnaires in Russian, English, and Spanish were distributed among 73 foreign students; 42 of the polled at that moment had studied or were still studying at Russian universities, while 31 others had never studied in Russia. Moreover, among the students surveyed were both those who studied the Russian language at Russian universities and those who had never studied the Russian language or culture. The respondents represented different cultures and ideological systems. The study involved representatives from North America, Latin America, Europe, the Middle East, Africa, and the CIS.

The respondents were invited to answer eleven questions in the questionnaire, ten of which were close-ended questions and there was one open-ended question. The questions reflected the following aspects: the attitude of the younger generation to Russia as an actor in international relations; the foreign students' perception of the ideological and ethnic component of Russian society; and those revealing the potential of "soft power" of modern Russia in the world. To process the study's results, we used a program for statistical data processing called SPSS Statistics. The main criteria for interpreting the results of the study were such parameters as the respondent's belonging to a particular country/region, as well as the factor of the student's presence in Russia (whether the respondent studied at Russian universities or not).

\section{WHERE DOES THE NEXT GENERATION GET INFORMATION?}

Since the formation of a country's image in people's minds occurs on the basis of available information, as well as on acquired emotional 
experience, it is very important to know which resource serves as the provider of information in shaping the image and ideas of a given state. This gives a better understanding, firstly, of the process of developing a country's image and, secondly, of the reasons why a certain image is formed. Russia invests heavily in foreign-language media, primarily Russia Today and Sputnik (Expensive media ... 2019). It is worthwhile to assess their impact on the younger generation and, accordingly, their current and future effectiveness.

According to the study, the Internet, where users independently control the information flow, is the source of information about Russia and events taking place in the country for most respondents (54.8\%). Traditional media are the sources of information for $32.8 \%$ of the respondents: $20.5 \%$ receive information about Russia from the national mass media, and $12.3 \%$ of the polled audience use Russian media, including Russia Today. However, for students in CIS countries, Russian periodicals and television are the prime sources of information $(66.7 \%$ of respondents in the CIS countries said so). Easy access and the popularity of the Russian mass media in CIS countries, as well as the language factor are the reasons for this. In addition, 5.5\% of all respondents admit that they know very little about Russia and do not receive any information about the country. It is worth noting that this position is characteristic of foreign students who have not studied at Russian educational institutions and make up $12.7 \%$ of the polled respondents who have never been to Russia. In addition to the mass media, Russian literature and movies are the surveyed respondents' other sources of information about the culture, politics, and lifestyle of Russian society (6.8\%).

A number of studies by the Pew Research Center confirm that the Internet is becoming an increasingly popular source of information. A survey of 4,581 participants held in the summer of 2018 found that $68 \%$ of American adults use social media as a news portal at least occasionally (Pew Research Center, September 2018). Respondents aged 18 to 49 prefer online resources for obtaining information in different formats: audio, visual, or text. For example, $76 \%$ of those questioned in this age group read electronic versions of periodicals on the Internet (Pew Research Center, December 2018). 
A Pew Research Center study conducted in Western Europe (Denmark, France, Great Britain, Sweden, Spain, the Netherlands, Italy, and Germany) in the autumn-winter of 2017 indicates that Europeans under the age of 50 use the Internet to get information more often than television or another source. Moreover, the share of respondents under 30 using the Internet as a daily information resource is $73 \%$. In the age group from 30 to $49,68 \%$ use Internet resources. Television, radio, and the print media are used by $38 \%, 33 \%$, and $12 \%$ of respondents aged 18 to 29 , respectively. In the group of Europeans from 30 to 49 years of age, the corresponding shares are $61 \%, 56 \%$, and $22 \%$.

The popularity of the Internet as an information resource is also confirmed by a study conducted by the Levada Center in September 2018 among young people in Belarus, Russia, and Ukraine. The survey results showed that more than half of the respondents (55-60\%) use the Internet, in particular, social networks, as the main source of information. According to the Levada Center poll, television has not lost its relevance yet and serves as a source of information for $44 \%$ of Russians, $40 \%$ of Ukrainians, and 36\% of Belarusians. According to the survey, the least popular information resources were the radio and the press (10\%-15\% of respondents) (Volkov and Goncharov, 2018).

In other words, online resources, including social networks, are by far the most popular information resources for young people around the globe. This trend is natural in modern society, because information technologies today have become widely developed to come into everyday use to take a firm foothold as one of the most popular channels of information and communication for the younger generation. The convenience and universality of Internet resources, as well as a large amount of information concerning all aspects of society's life contribute to this in many respects (Pew Research Center, October 2018). This fact must be taken into account in determining the strategies to promote the country's image. For this, foreign language resources, such as Russia Today, Sputnik, and The Moscow Times should generate much more content for the social media targeted at younger users. Just looking at such image pages as "Russians are awesome-We love Russia," is enough to see that the content is not very diversified; there 
are clips about classical Russian culture and architecture, folklore, and military events-parades, weapons, and Victory Day. The content of the national myth that they broadcast is extremely fragmented and quite archaic. It is an image of the past without an image of the present or the future.

\section{A VIEW OF RUSSIA AND ITS PLACE IN THE INTERNATIONAL RELATIONS SYSTEM}

Policies pursued in world affairs exert great influence on a country's image on the global stage. As an independent actor in international relations, modern Russia, for most respondents regardless of the host country where the polled students receive instruction, is a global leader playing a proactive and significant role in world politics (65.8\%) (Graph 1). This opinion is shared by most foreign students from Africa, the Middle East, and Latin America (100\%, 83.3\% and 83.3\%, respectively), as well as $66.7 \%$ of Europeans and $20 \%$ of the surveyed students from North America.

In second place (17.8\% of respondents) one finds the opinion that Russia is a country with an ex-superpower complex, which is only trying to influence world politics. Russia is seen as a regional power, with its influence confined to the post-Soviet space, by $8.2 \%$ (Graph 1). About $4.1 \%$ of the audience look at Russia as a potentially rogue country (Graph 1). Moreover, such an attitude is manifested in answers offered by representatives of the European continent $(7.1 \%$ of the polled Europeans).

The question about the role of Russia in the modern system of international relations highlights a clear divide between the groups of students who study at Russian universities and elsewhere. The former are more skeptical about modern Russia's status in the world: only half (50\%) recognize Russia as a global leader, $42.9 \%$ describe Russia as a regional power, enjoying influence only among CIS countries (11.9\%), or as a successor of the Soviet Union without the Soviet potential (31\%) (Graph 1). Interestingly enough, this opinion is characteristic only of those surveyed participants who are studying in Russia at the moment or studied there in the past (31\% of the polled studying in Russia). 
In turn, students who do not study at Russia's educational establishments are more eager to consider Russia a significant actor in global politics (87.1\%). Opinions of Russia as a regional power or as a rogue state are very rare $(3.2 \%$ and $6.5 \%$, respectively), and no one regards Russia as a country with an ex-superpower complex (Graph 1).

Graph 1. Russia in World Politics

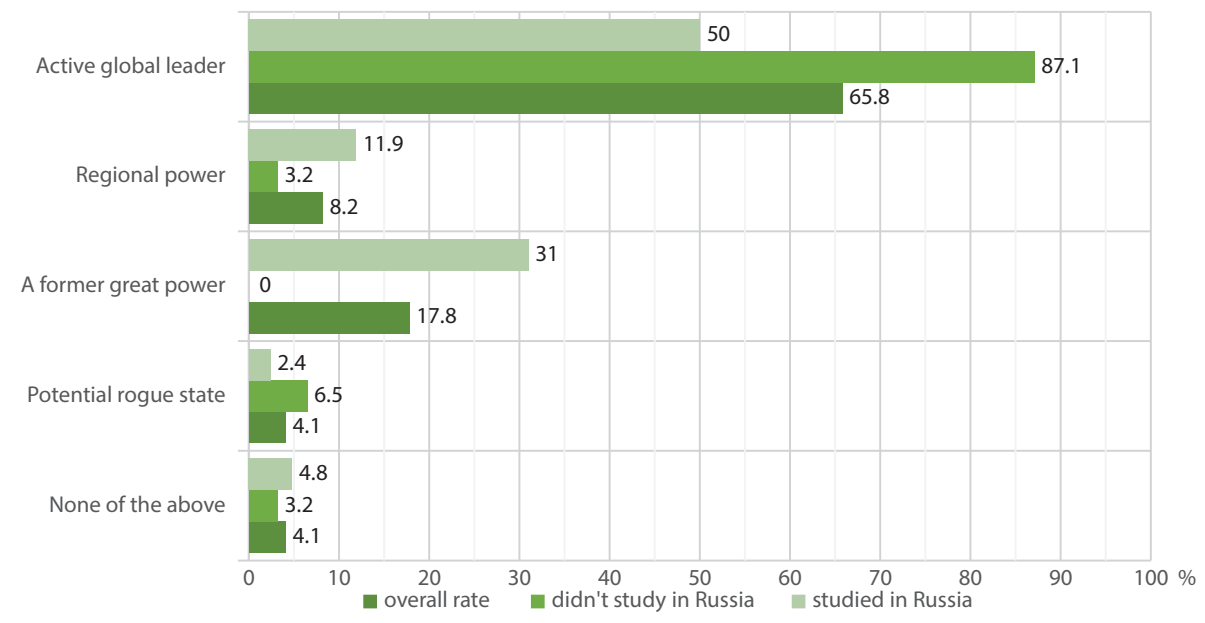

The results demonstrate that in the process of getting first-hand experience of Russia's everyday realities, young people are more skeptical about the potential of Russian society and the state in terms of both domestic political development and Russia's role in foreign policy. The experience of studying in Russia has a more negative impact on the perception of the country as a global geopolitical power and a promising center in a multipolar world.

\section{RUSSIA IN THE INTERNATIONAL RELATIONS SYSTEM}

In terms of international relations, it is also important to note that in the modern era of globalization processes, regional unions and international organizations, and the strengthening and expansion of bilateral and multilateral relations, have begun to play an increasingly larger role. The creation of international organizations contributed to the emergence of a new institution of international communication, 
which today has become one of the "backbone elements of world politics and international relations" (Voronkov, 2015). Moreover, some researchers point to a downtrend in the influence of nation states on world politics and to the formation and development of such centers of power (political and economic) as regional unions and blocs, with common or close cultural and civilizational factors serving as the force that keeps such unions together (Pantin and Lapkin, 2018).

Russia is a member of many international associations and has one of the leading roles in the BRICS group. According to N. Unnikrishnan, the vice president of the Observer Research Foundation, BRICS at the present stage of development is a "good tool" for establishing multipolarity, while the organization's member-countries should play a role in the world and establish the rules of the world order themselves (Ruskline.ru, 2015).

Graph 2. BRICS is...

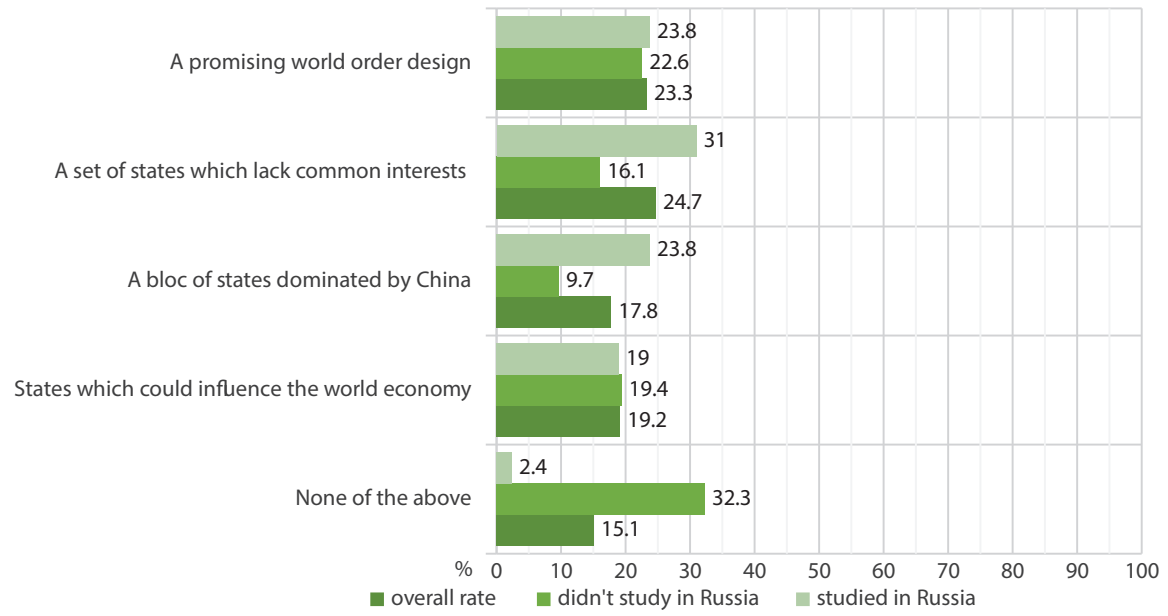

The respondents were split over the further development of BRICS and its prospects in world politics, with no traces of unanimity for now. $23.3 \%$ of respondents view BRICS as a political bloc that can offer a promising alternative model of world development with a potential extending well into the future; $17.8 \%$ of foreign students speculate that BRICS is gradually transforming into a bloc of potential strategic 
partners where China, and not Russia, will be in the commanding position. The proportion of respondents to these questions who studied and did not study in Russia are very similar (Graph 2).

At the same time, $19.2 \%$ of respondents say that BRICS will have economic influence, but no political weight. $24.7 \%$ of foreign students say that BRICS today is an abstract set of countries that lack common interests and effective cooperation strategies (Graph 2). Some disagreements on this score are noticeable between the groups of students receiving a Russian education and their counterparts elsewhere. A large number of foreign students in Russia believe that BRICS is nothing but a list of countries without a clear agenda for further development, or they consider the organization as a bloc of states where China rules the roost (Graph 2).

In 2017, Russia's vector towards interaction with China, known as the "Turn to the East," was already reflected in the respondents' answers. Today, the concept of BRICS is gradually fading from the international political agenda, while the trend towards strategic partnership with China is gaining strength.

Regarding the future of Russia in the system of international relations, $56.2 \%$ of foreign students are certain that Russia will pursue its own foreign policy aimed at achieving the interests of the state and ensuring the country's security; $23.3 \%$ of respondents say that Russia will enforce its foreign policy in partnership and with the participation of another emerging power-China; $13.7 \%$ of the surveyed see Russia's future as a kind of bridge connecting the West and the East, or, in other words, a broker in world politics; and $4.1 \%$ believe that Russia will not be a significant player in the international arena in the future. It is also noteworthy that not a single foreign student surveyed thinks Russia will eventually join the EU (Graph 3).

Such views reflect the current situation. For the older generation, the idea of Russia's place in Greater Europe and even the European Union was part of the discourse of the 1990s. In fact, these approaches continue to be relevant for certain intellectual circles, for example, members of the European Dialogue expert group. However, for young foreigners in Russia, this agenda is already totally irrelevant. 
Graph 3. The future role of Russia in the world order

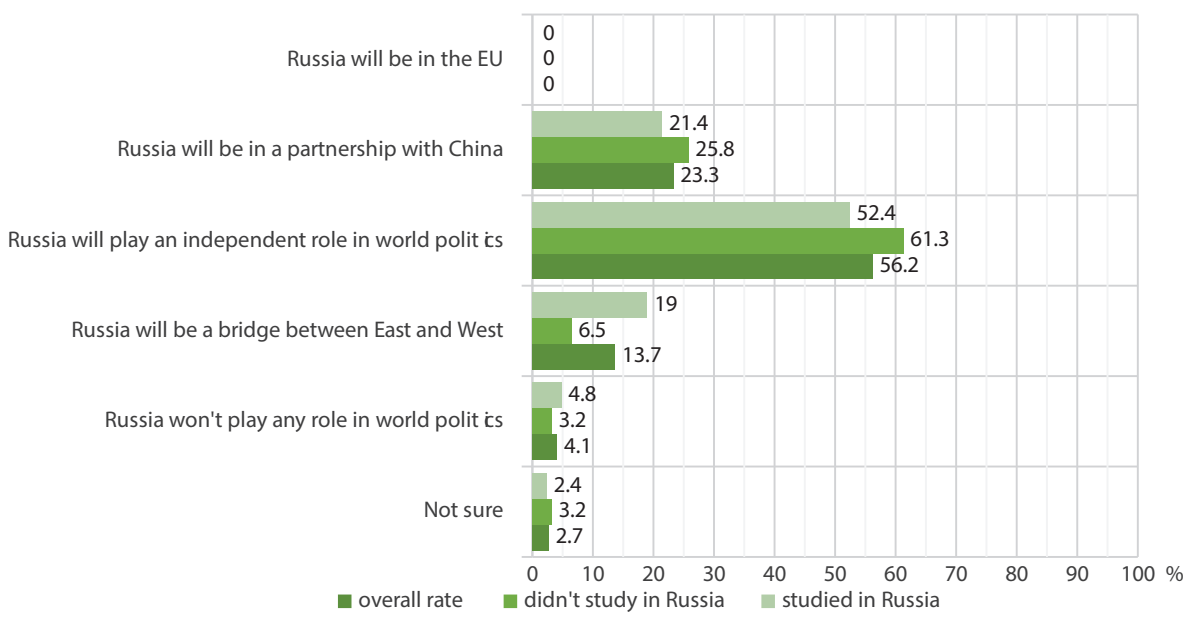

\section{WHAT DOES RUSSIAN POLITICS LOOK LIKE?}

To a large extent a country's image is determined by the features of its domestic policy and political regime. Modern Russia's political regime, although defined in the Constitution as democratic, is in many ways different from Western democracies. Currently Russia has developed a unique (Kondrashev, 2013), peculiar, and specific type of political regime combining certain features of democracy and authoritarianism (Baranov, 2017). Such a political regime can be described as hybrid or transitional (Kharitonova, 2017; Dorozhkin, 2016; Skornyakova, 2012) or even a "competitive authoritarian regime" (Levitsky and Way, 2010).

A majority of foreign students surveyed (56.2\%) say Russia today has a hybrid regime, a crossbreed of authoritarianism and democracy. This viewpoint is shared by $61.9 \%$ of respondents studying in Russia and $48.4 \%$ of students who do not study at Russian educational establishments (Graph 4). The description of modern Russia's system as authoritarianism or an illiberal democracy enjoys support from $100 \%$ of respondents from CIS countries. This is a remarkable result that deserves further analysis and research. It requires more detailed, in-depth interviewing. 
The idea that Russia's system is authoritarian is shared by $16.4 \%$ of the respondents. Authoritarianism in the Russian political system is most often seen by students who did not study in Russia. They tend to agree with a simplified picture drawn by biased media. Another 5.5\% of respondents have the opposite opinion. The way they see it, Russia has a liberal-democratic system. At the same time, 12.3\% call Russia's political system democratic, but with certain specifics (Graph 4).

\section{Graph 4. The political system in Russia}

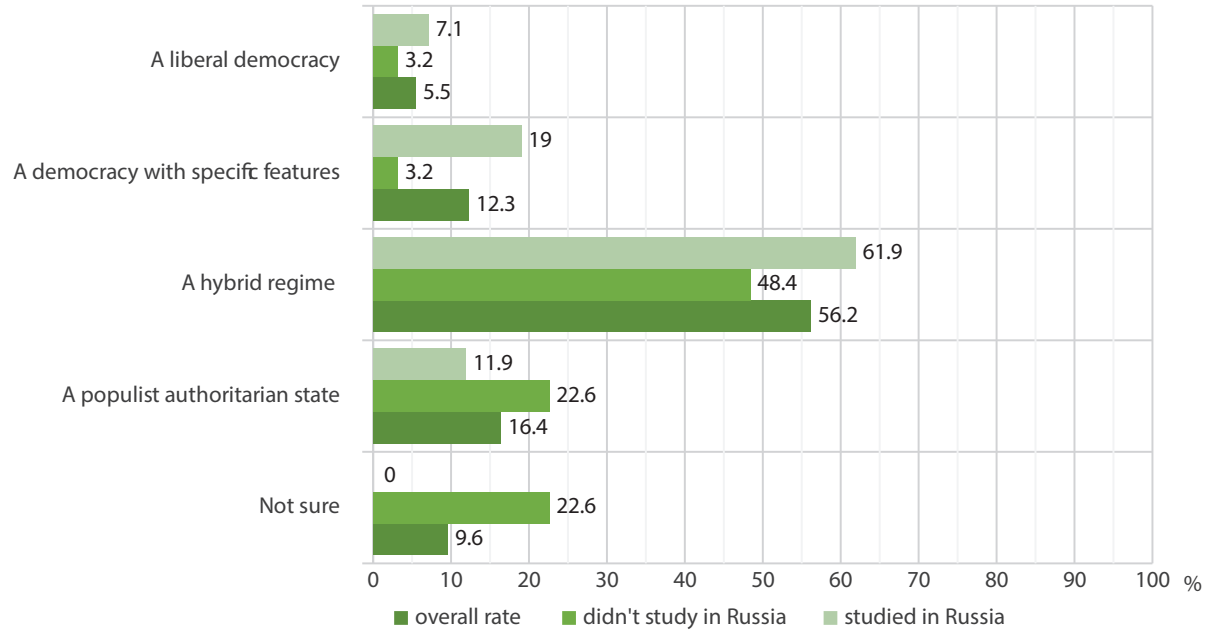

To sum up the intermediate results, we can conclude that, according to the ideas of foreign students, Russia is a strong state with a hybrid political regime. It will retain one of the key positions in world politics in the future. Most of the surveyed respondents share this vision of Russia. However, in the system of international relations, Russia looks better in the eyes of foreign students who have not studied at Russian universities, although this difference is not significant and can be seen only in answers to certain questions. Students with firsthand experience of studying in Russia naturally see the situation more comprehensively. They are far more skeptical about Russia and its development capabilities. Also, it is much more typical of them to note the democratic features of the modern Russian state. 


\section{CIVILIZATIONAL FACTORS AND RUSSIAN SOCIETY'S VALUES}

Civilizational distinctions between peoples and different ideological and moral guidelines are an important factor for a positive or negative image of the country in question. The nature of Russian civilization is influenced by many factors, including geopolitical position, the multiplicity of ethnic groups and nationalities, multi-confessionalism, the historical past, and cultural heritage.

The surveyed respondents were also asked to determine to which civilization they would attribute modern Russia.

As many as $58.9 \%$ positioned Russian society as a unique civilization in its own right connecting Europe and Asia. At the same time, 27.4\% of the respondents ranked Russia as a member of the European family of peoples on the basis of cultural and political development. And $6.8 \%$ of foreign students attributed Russia to Asia (Graph 5).

The ways in which foreign students at Russian universities and elsewhere see Russia's civilizational affiliation do not differ drastically. However, it can be noted that the rate of those who noticed the uniqueness of Russia as a civilization is higher among foreign students who did not study in Russia (Graph 5).

\section{Graph 5. The civilizational affiliation of Russia}

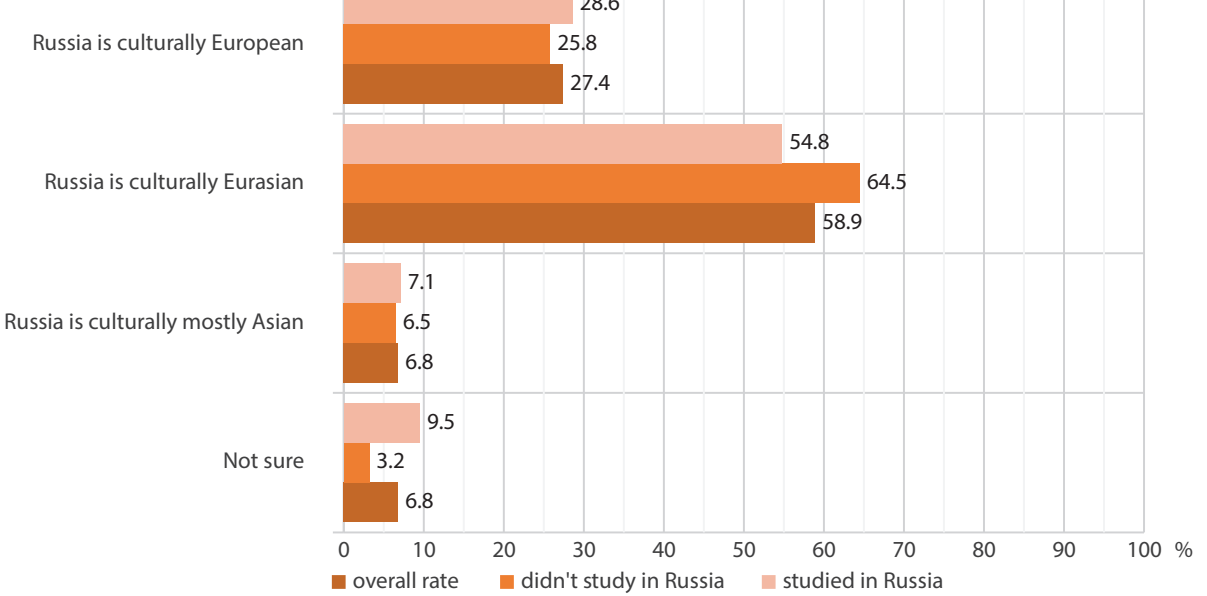


It is noteworthy that $100 \%$ of the surveyed respondents from CIS countries perceive Russia as a unique civilization, displaying both Oriental and European features. At the same time, 60\% of North American students place Russia in Asia, while a third of Europeans regard Russia as a European country.

Such a view of Russia and its place in the world corresponds with the perceptions of the Russians themselves. Over the past decade Russia's residents have steadily drifted away from Europe in their selfidentification. While in 2008, 52\% of respondents considered Russia to be a "European country," in 2019 only 37\% said so. Accordingly, the share of those who consider Russia a "non-European" country has increased to $55 \%$ from $36 \%$. Russians now look more certain regarding their own identity. When asked "Do you consider yourself a European?" far fewer respondents found it difficult to answer (only $4 \%$ today in contrast to $13 \%$ before). The respondents who replied "definitely yes" grew by a tiny two percentage points (to $12 \%$ from $10 \%)$, while the frequency of the answer "definitely not" surged up noticeably to $35 \%$ from $21 \%$ (Levada, 2019). The policy of building a Russian identity in line with civilizational uniqueness has been productive and brought about corresponding changes in the minds of both Russians and foreigners. Russia's proactive and independent foreign policy in the Middle East is a major contributing factor.

An orientation towards traditional values, including the protection of the traditional family, gender roles, collectivism, and patriotism is an important component for the Russian state narrative. Also, according to Russia's National Policy Strategy up to 2025, the goal of Russian national policy is to preserve and support traditional ideological and moral values as the basis of Russian society (Pravo.gov.ru, 2012). Yet Russia these days is witnessing a shift in the ideological orientation of Russians in the context of deep socio-political changes taking place inside the country and around the world (Tishkov, 2018). According to the results of a study by the ZIRCON group, among the values uniting modern Russian society are "one's own health and the health of the loved ones" (76\%) and "family happiness and children" (62\%). At the same time, it is characteristic of Russia's secular society that 
religious faith as a value is important to only $6 \%$ of respondents, which approximately corresponds to the number of practicing believers. In general, the ZIRCON survey indicates the fragmentation of Russian society in terms of values, which, in turn, testifies to the absence of consolidating factors in the ideological and moral dimension of society. At the same time, the ZIRCON study confirms the traditional character of Russian society, in particular, regarding family values and gender roles: $85 \%$ of respondents opposed same-sex marriage, while only $4 \%$ support this initiative, and another $7 \%$ are ready to allow such marriages only in exceptional cases (Zircon.ru, 2019).

Regarding the appropriateness of pursuing a policy to preserve traditional values in the era of globalization, our survey found no unanimity. For instance, $27.4 \%$ of the respondents believe that traditional values are acceptable only for private life, but not at the level of official policy. This opinion is shared by $26.2 \%$ of those who studied at Russian universities and $29 \%$ of foreign students who do not study in Russia. At the same time, $20.5 \%$ of the respondents disagree with such views and consider the preservation and dissemination of traditional values to be correct, because individualism and liberal values adversely affect society and its development. This opinion is shared by $26.2 \%$ of the surveyed foreign students living in Russia. Among youth representatives who are not studying at Russian universities, 12.9\% said the policy to protect traditional values was right (Graph 6).

Some foreign students believe that the protection of traditional values is not relevant today and leads to the de-modernization of society (19.2\%). They believe this is not a sincere viewpoint, because in modern Russian society traditional values are no longer relevant (12.3\%). 29\% of foreign students who have not studied in Russia think that traditional values in modern society are archaic and any attempt to preserve them leads to social stagnation. By contrast, the rate among those studying at Russian educational institutions is only $11.9 \%$ (Graph 6).

It is very appropriate to look at the distinctions in answers that vary from one region of the world to another. The perception of traditional values and attitudes towards them are highly correlated 
with the culture of the respondent's country of origin. For immigrants from CIS countries, Asian countries, and Latin American countries the closest viewpoint is that the "protection of traditional values is right, because liberal values and the values of individual choice will eventually ruin society." People from Africa and North America are inclined to believe that "the protection of traditional values is not right, because traditional values are possible only in private life and not at the level of official policy." Also, immigrants from North America and Europe tend to believe that this is "an outdated position, because it pushes the country towards social de-modernization and stagnation." In general, we obtained a predictable result that enables us to conclude that the process of getting an education does not transform the deep value attitudes associated with ideas of the family, gender roles, etc., acquired in the earlier stages of socialization. In this sense, they differ significantly from political values, which are more often acquired during the education process.

\section{Graph 6. Attitude towards the policy of advocating traditional values in Russia}

It is right because liberal values and individual choice undermine society

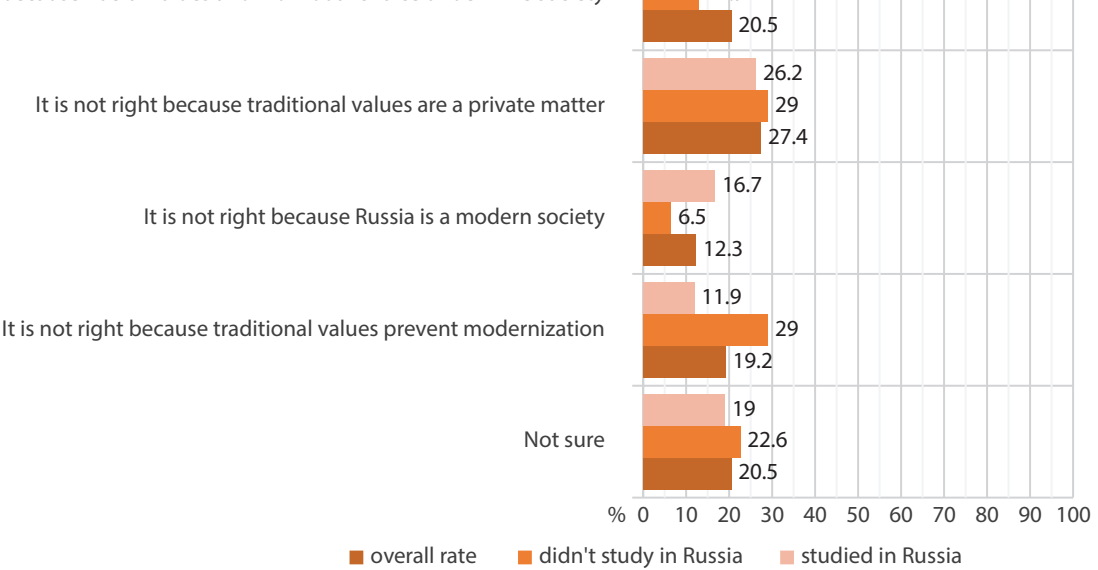

As far as distinctions in the value preferences of different societies are concerned, $72.6 \%$ of foreign students surveyed believe that the value systems of Russian society are different from the values of the society 
the respondent belongs to. But at the same time, $54.8 \%$ say that values do not differ radically, while $17.8 \%$ find this distinction significant; $24.6 \%$ believe that values are common, with $4.1 \%$ of them certain that values are the same for all people (Graph 7).

\section{Graph 7. Differences in the value systems of Russia and respondents' countries}

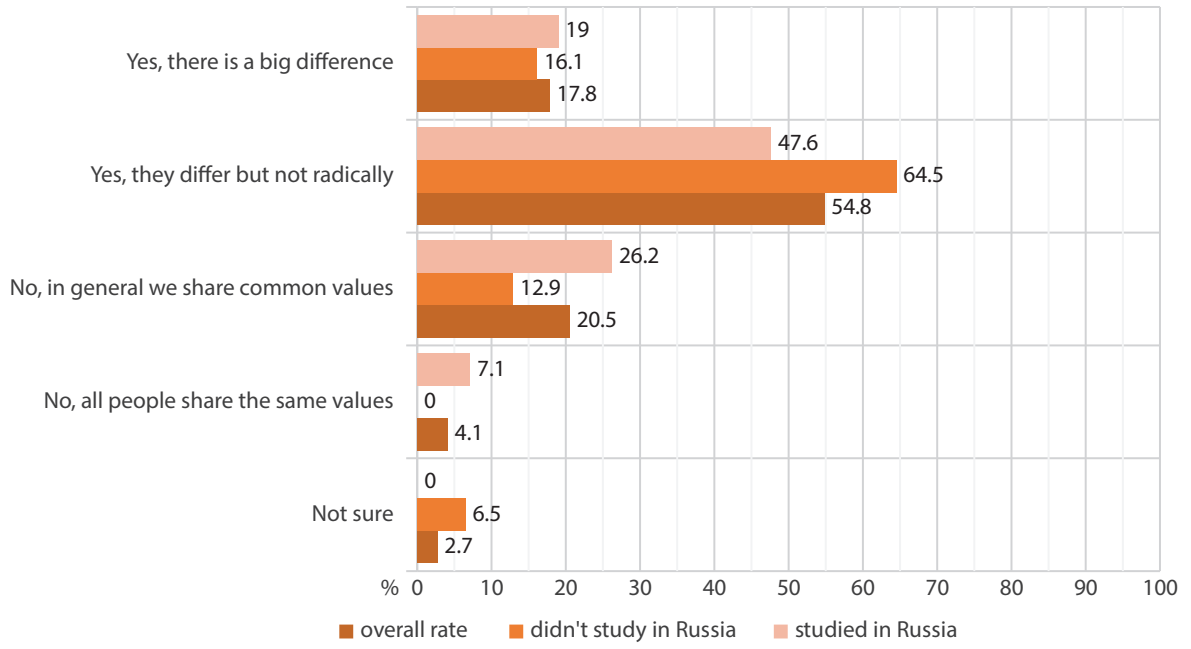

When speaking about common values it is worth noting that, despite a shared past, $66.7 \%$ of the surveyed students from CIS countries believe that the values of their countries and the values of modern Russia differ, although not fundamentally. That all people share common values is the opinion of half of the respondents from the Middle East, $40 \%$ of students from North America, $33.3 \%$ of respondents from the CIS and Latin America, and 19.1\% from Europe. In the answers to this question, only respondents from the North American region stand out: most of them answered that values vary greatly.

Another special feature of Russian civilization is its ethnoconfessional makeup. Russia is home to about 100 indigenous peoples. Also, there are more than 60 peoples and ethnic groups, the bulk of which live outside Russia (Bogoyavlenskiy, 2018). Russia consists of ethnicity-based republics, autonomous districts, and territories. Russia pursues a policy to preserve and develop the cultures of 
individual ethnic groups and peoples. Russia's multi-ethnic and multiconfessional nature can be considered as "its specific civilizational attribute, which in many respects constitutes the country's advantage" (Mchedlova, Gavrilov and Shevchenko, 2015).

Asked if the ethnic diversity of Russian society is an advantage in the era of globalization or whether it breeds tensions and conflicts in society, a majority of respondents (58.9\%) said this diversity is an advantage, while just $5.5 \%$ believe that it is an obstacle to the further development of Russia. Another 19.2\% see ethnic diversity as a source of social conflicts and tensions (Graph 8).

Among those who studied at Russian universities, $64.3 \%$ positively assess the existence of many ethnic groups in Russia, while $2.4 \%$ see this as an obstacle to the modernization of society. In the group of students who did not study in Russia, the rates were 51.6\% and 9.7\% (positive and negative perceptions, respectively). Moreover, almost a quarter $(23.8 \%)$ of foreign students with the experience of living in Russia point to multi-ethnicity as a source of conflicts in society. Among foreigners without a record of studying in Russia, the rate is 19.2\% (Graph 8).

Graph 8. The ethnic diversity of Russia is...

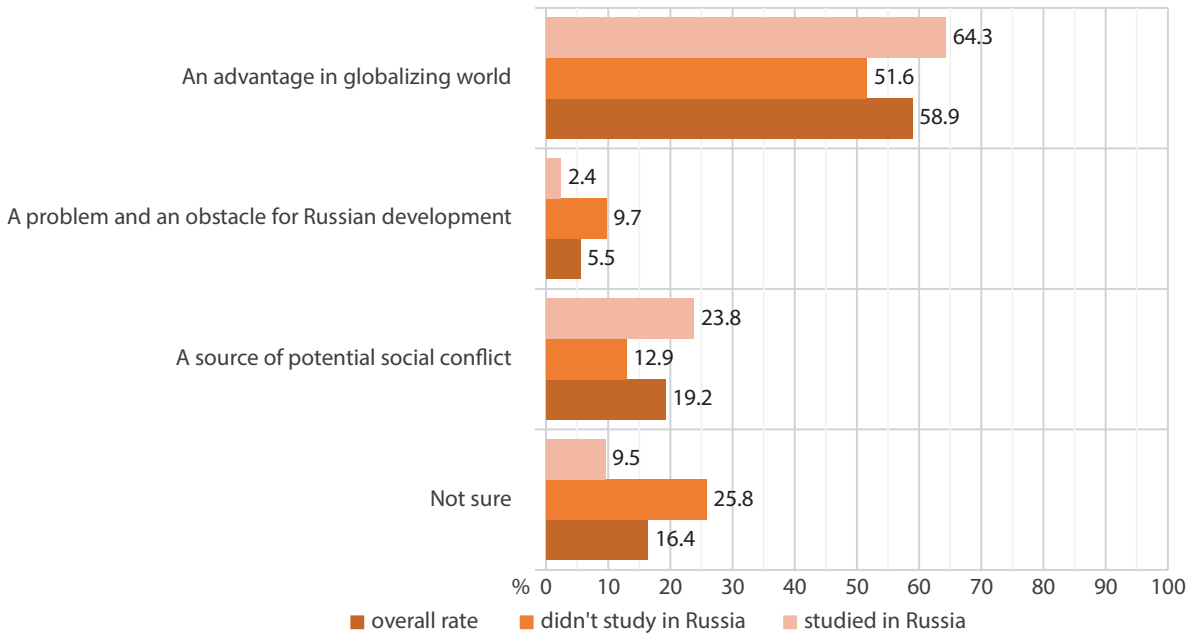


The greatest distrust towards multiethnicity as a source of contradictions and conflicts was expressed by students from CIS countries (33.3\%). Representatives from the Middle East and North America, on the contrary, overwhelmingly said that Russia's great variety of ethnic groups was an advantage in the context of globalization ( $83.3 \%$ and $80.0 \%$ respectively).

As one can see, most respondents recognize the uniqueness of Russian civilization and the advantage of a multiethnic society in Russia. However, not all representatives of young foreign students share Russia's policy of preserving traditional values, although they acknowledge that the value systems of different communities do not differ radically. Foreign students' pessimism regarding the protection of traditional values in Russian society to some extent reflects the mood of Russian society itself, where skeptical views about the sincerity and the need for a state policy to protect traditional values have been growing in recent years, especially among the younger generations.

\section{RUSSIA'S SOFT POWER}

Soft power policy is one of the key factors for a positive image of a state beyond its borders.

The concept of "soft power" was first used by Joseph Nye in his book Bound to Lead: The Changing Nature of American Power (1990). Subsequently he developed this concept in Soft Power: The Means to Success in World Politics (2004). Nye defined "soft power" as "the ability to achieve goals through attraction rather than coercion" (Nye, 2004). In the studies of Russian scientists, "soft power" most often refers to "nonmilitary methods of influencing the opposite side" (Lebedeva, 2017).

For modern states, the "soft power" policy is especially relevant. It is an integral component of the foreign policy of countries as a whole and makes it possible to achieve longer-term results (Lebedeva and Kharkevich, 2014). Soft power in information society is becoming "one of the most important resources of influence" (Ponomareva, 2016).

Russia has an enormous potential and vast opportunities for using "soft power" in its foreign policy (Lebedeva and Kharkevich, 2014), which, however, remain largely untapped. The main sources of 
Russia's "soft power" are diplomacy, cultural and historical heritage, and education. Since 2016, Russia has been included annually in the global Soft Power 30 index, compiled by the British PR agency Portland Communications and the USC Center on Public Diplomacy, which ranks the 30 most influential countries of the world in soft power terms. Russia was in 27th place in 2016. In 2017, it was 26th, and 28th in 2018.

In the reviewed survey, the existence of effective soft-power factors in Russia was recognized by $58.9 \%$ of the polled foreign students. However, $34.2 \%$ of them believe that Russia's modern soft power is based, first of all, on the achievements of the past-a rich history and classical culture. Accordingly, $24.7 \%$ believe that in the modern world Russia's soft power is among the most significant ones. A negative, repulsive image of Russia is noted by $11 \%$ of students from foreign countries, while $21.9 \%$ believe that Russia's image is balanced by negative and positive factors (Graph 9).

At the same time, most foreign students studying in Russia recognize the presence of soft power in modern Russia only by virtue of the previous merits of the state (40.5\%) (Graph 9). As many as $66.7 \%$ of CIS respondents say so, too. The largest percentage of foreign students who do not study in Russia say Russia's soft power factors are among the most significant ones in the modern world (32.3\%) (Graph 9).

\section{Graph 9. Does Russia have "soft power"?}

Yes, it has a lot of soft power as one of the most powerful countries in the world

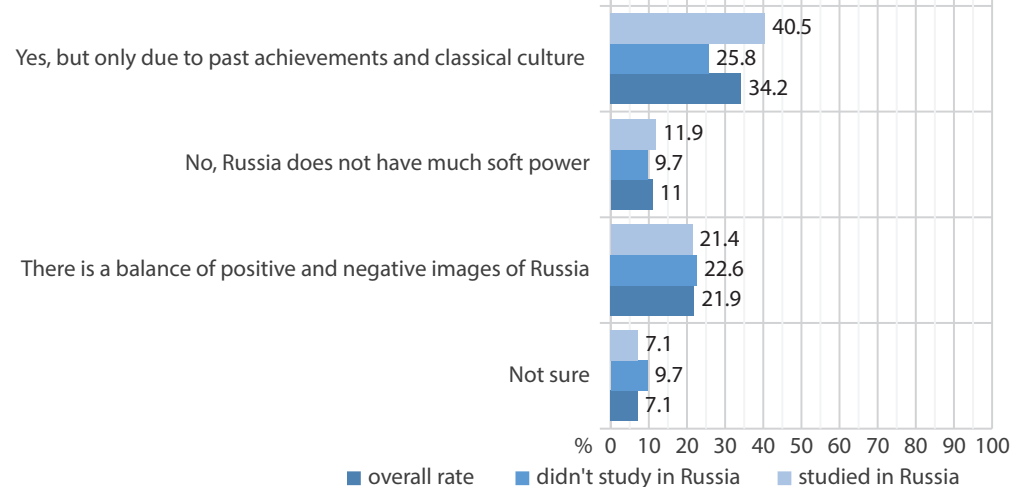


Four in ten respondents $(41.1 \%)$ agree that the main potential of Russia’s soft power lies in its cultural and historical heritage and arts, and $27.4 \%$ of respondents perceive Russian soft power as an alternative to Western liberalism. Innovations, including IT technologies, and education are poorly represented (9.6\% and $8.2 \%$, respectively), while religion was not marked by respondents as a resource of soft power in Russia at all (Graph 10).

Those who studied in Russia and others who did not are divided over the potential of modern Russia's soft power. More than half of foreign students at Russian universities (52.4\%) agree that Russia's soft power should be looked for in its culture and arts, while $51.6 \%$ of respondents who have never been to Russia see the potential of Russia's soft power as an alternative to Western liberalism (Graph 10).

\section{Graph 10. The potential of the Russian "soft power"}

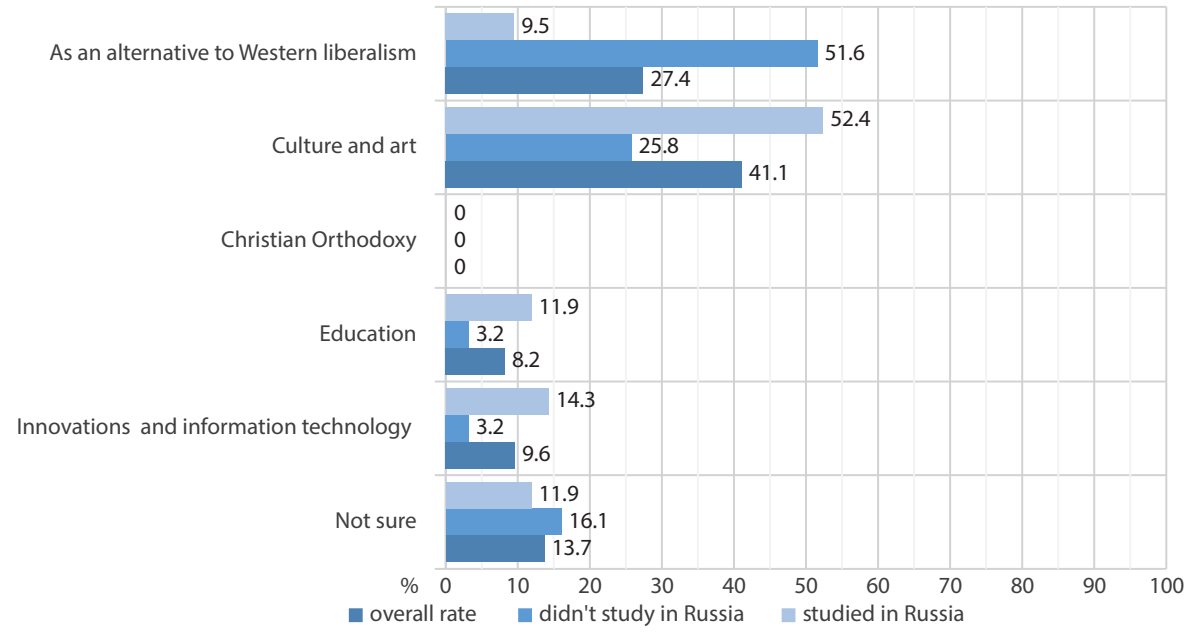

While both groups of respondents-students who did not study at Russian universities and others who study in Russia-admit that Russia has soft power, significant disagreements were highlighted regarding the nature of soft power. These factors, according to the results of the study, can be considered in the context of three aspects: 1) the soft power of Russia as one of the most significant in the modern world; 2) 
the soft power of modern Russia is based on the merits of past years, including cultural heritage; 3 ) Russian soft power as an alternative to Western influence.

\section{ASSOCIATIONS}

The open-ended question implied that respondents would name up to five characteristic words that they associate with Russia.

In response, 156 associations were formulated on the basis of which one can say there is a wide variety of ideas foreign student have about Russia. Students studying in Russia offered 109 answers, while students who did not study in Russia formulated 69 associations.

Based on the answers received, several groups of associations can be distinguished: political ("power," "counter-power," "authoritarianism"), socio-economic ("corruption," "inequality," "sanctions"), climatic and geographical ("cold," "big," "snow"), cultural and scientific-technological ("Dostoevsky," "culture," "Gagarin," "space”), ethnological ("multinational," "Russianness"), historical (“USSR," "revolution," "Zhukov”), stereotypical symbols ("matryoshka," "balalaika," "bear"), etc.

\section{Graph 11}

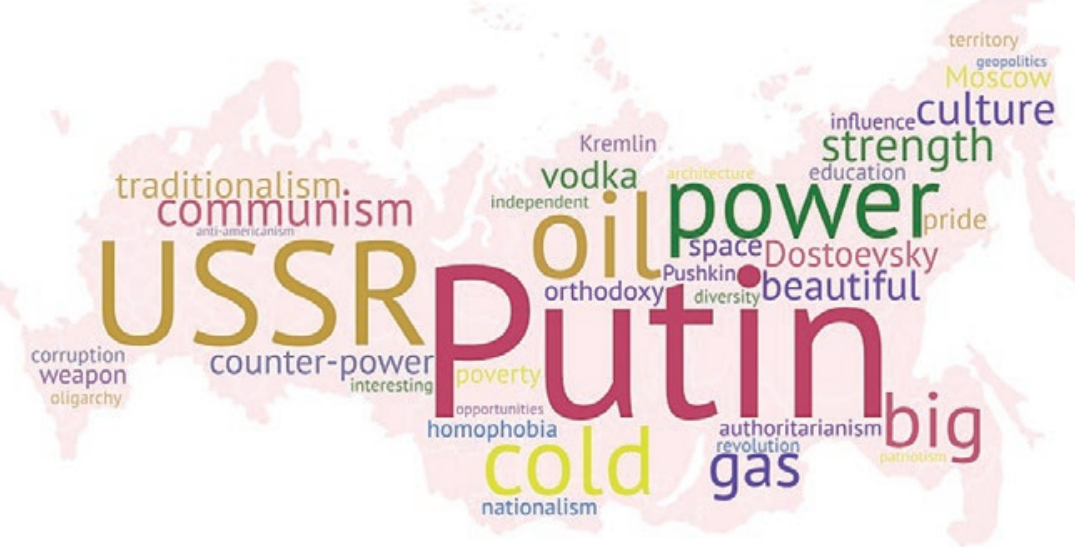

Vladimir Putin was the most frequently mentioned association with Russia among foreign students. The answer "Putin" was repeated 13 times (17.8\% of respondents). The second most frequent answer 
was "USSR," with which $12.3 \%$ of respondents associate modern Russia. The word "power" was mentioned eight times. Also, the list of most popular characteristics included "cold" (six references), "oil," "communism," "power," "counter-power," and "traditionalism" (five references each) (Graph 11).

In the answers offered by students who studied in Russia, "Putin" is also the most frequent association (16.7\% of respondents), while in the answers by those who did not study at Russian universities, "Putin" (19.3\%) follows the term "power" (22.6\%), which is mentioned most often (Graph 12).

Graph 12

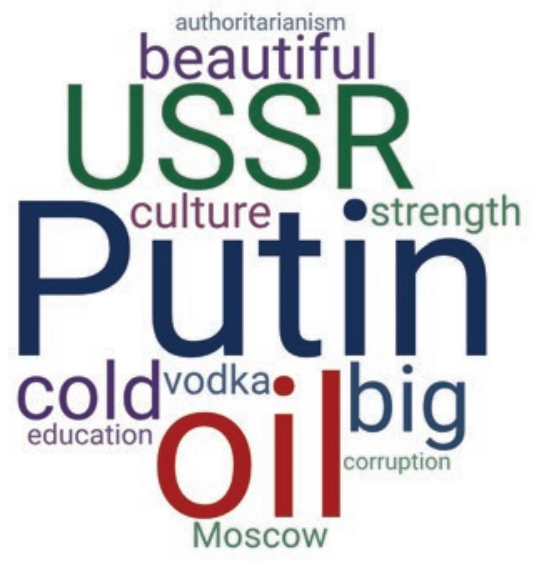

Graph 13

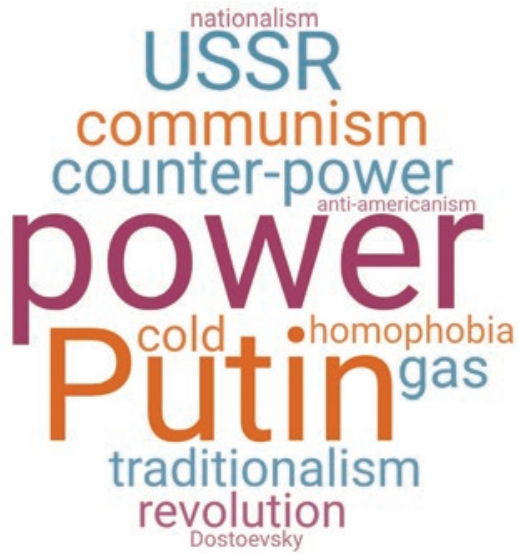

Russia is associated with the USSR mainly in the minds of those students who studied or study in Russia (six references). Those who do not study in Russia mentioned the concept "Communism" more often (four times) than "USSR," which was mentioned three times, as often as "revolution" and "homophobia." Also, among the answers by those who did not study in Russia, the term "counter-power" was quite popular, while no such association is found in answers by foreign graduates and students of Russian universities. The list of associations mentioned by foreign students studying in Russia included such labels as "oil," "big," "beautiful," "cold," "power," and "culture." Such 
associations are weaker in the group of foreign students who did not study in Russia (Graph 13).

Among the associations that are unique to foreign students who do not study in Russia, one can single out such categories as "counterpower," "alternative model," "anti-Americanism," as well as "other" and "uniqueness."

At the same time, stereotypical ideas about Russia are present in most answers of those respondents who studied in Russia. They include such words as "matryoshka," "birch tree," "bear," etc., which are not found in the answers of young foreigners who do not study at Russian universities. "Balalaika" is the sole exception. It is worth noting that such stereotypes about Russia as "cold" and "vodka" are found in both cases, but they figure more often on the list of associations mentioned by students studying in Russia.

In a word, it can be noted that the group of respondents who do not study in Russia tends to opt for ideologically loaded associations, while those who studied in Russia pay more attention to emotional, aesthetic, and geographical factors.

This survey identified three aspects of how Russia is perceived in the minds of foreign students: 1) Russia as a world power with its own policy; 2) Russia as a country with a former great power complex; and 3) Russia as an alternative to the Western world.

Most foreign students see Russia as a strong state with global influence. The prevailing opinion is that Russia will retain one of the leading positions at the global level in the future. Insignificant disagreements occurred on the issue between students who studied at Russian universities and those who did not. Moreover, those who lived in Russia are less optimistic about the role of Russia in world politics. Foreign students studying at Russian universities more often speak about Russia as a country with a former great power complex.

The same tendency is observed on the issue of Russia's soft power. With a certain degree of abstraction three aspects can be singled out: 1) Russia's soft power as one of the most significant in the modern 
world; 2) the soft power of modern Russia is based on the merits of the past, including its cultural heritage; 3) Russian soft power as an alternative to Western influences.

Foreigners who studied in Russia mostly see the potential of Russian soft power in the historical and cultural heritage, while students who have not studied at Russian universities tend to contrast Russia's soft power factors with Western liberalism. Nevertheless, the presence of soft power resources in modern Russia is recognized by both groups of respondents.

Also, as a result of the conducted survey, it was found that although a majority of respondents recognize the civilizational uniqueness of Russia, they do not see fundamental distinctions between the values of Russian society and the society to which they belong. Moreover, Russia's traditionalism-based values are not shared by all survey participants. They describe the Russian authorities' policy to protect and disseminate traditional values as wrong, insincere, or outdated.

The divergence of opinions between students who study in Russia and elsewhere is noticeable when it comes to associations. Representatives of foreign youth studying in Russia rely more on their first-hand, day-to-day experience and the emotional component. This is not so with foreign students who do not study in Russia. They tend to associate Russian society with notions based on different ideologies. As a result, foreign students who study in Russia more often refer to it as a country with a former great power complex. Most of those who have not studied in Russia think that Russia is a kind of alternative to the West and Western values.

By and large the study found that modern education at Russian universities does not fully contribute to shaping foreign students' positive perception of Russia. While no such task is set to the Russian education system at the legislative level, it is precisely education that can become an effective resource that may help young foreign students develop a positive image of the Russian state.

The study highlighted a number of shortfalls and the need to make adjustments to both the questionnaire and the sample audience. The age criterion turned out to be irrelevant within the framework of this 
study, because no significant distinctions were identified in different age groups. For this reason, age was not included in this report of the survey.

In the future, researchers will attempt to probe into the role and influence of educational migration as a resource to spread the culturaland-value message of Russian civilization among foreign students. Plans are in place for a wide-scale survey with a large representative sample and one which is much wider in geographical scope. The next survey will also emphasize the quality of questions, mostly openended ones, and thorough analytical work.

\section{References}

273-fz.zf, 2012. Ob obrazovanii v Rossiyskoi Federatsii. Federal'ny zakon ot 29 dekabrya 2012 g. No.273-FZ. ["On Education in the Russian Federation." Federative Law No. 273-FZ of 29 December 2012]. Available at: http://xn--273-84d1f.xn--p1ai/zakonodatelstvo/federalnyy-zakon-ot-29-dekabrya-2012-gno-273-fz-ob-obrazovanii-v-rf [Accessed 01 March 2019].

Astakhov, Ye.M., 2014. Sub'yektivnyie zametki o nekotoryh aspektah "myagkoi sily" [Subjective Notes on Some aspects of 'Soft Power"]. Vestnik MGIMO Universiteta, 1 (34), pp. 45-53.

Baranov, P.P., 2017. Sovremenny politichesky rezhim Rossii, yego konstitutsionnaya legalizatsiya, legitimatsiya i legitimnost' [Modern Political Regime of Russia, Its Constitutional Legalization, Legitimation and Legitimacy]. Severo-Kavkazskiy yuridicheskiy vestnik, 1, pp. 121-128.

Bogoyavlensky, D.D., 2018. Etnicheskoye i religioznoye mnogoobraziye Rossii. [Ethnic and Religious Diversity of Russia]. In: Tishkov, V.A. and Stepanov, V.V. (eds.) Etnicheskoye i religioznoye mnogoobraziye Rossii [Ethnic and Religious Diversity of Russia], 2nd Edition. Moscow: IEA RAN, pp. 22-62.

Dorozhkin, Yu.N., 2016. Politicheskaya sistema sovremennoi Rossii: demokratiya ili avtoritarizm? [Political System of Modern Russia: Democracy or Authoritarianism?] Vlast', 24 (8), pp. 14-18.

Dutkiewicz, P. and Kazarinova, D.B., 2017. Konets epohi globalizatsii: prichiny i posledstviya [The End of the Globalization Era: Causes and Outcome]. Vestnik RUDN. Seriya: POLITOLOGIYA, 19 (1), pp. 7-14.

Finance.rambler.ru, 2018. Expensive Media. How Much Does the State Media Product Cost to the Budget? Available at: https://finance.rambler. 
ru/business/39575182/?utm_content=rfinance\&utm_medium $=$ read_ more\&utm_source $=$ copylink

Kazarinova, D.B., 2018. Akademichesky dialog mezhdu Rossiyei i Yevropoi v usloviyah "umnyh", 'emotsional'nyh", i "intellektual'nyh" sanktsyi [Academic Dialogue between Russia and Europe in the Conditions of "Smart", "Emotional" and "Intellectual" Sanctions]. In: Kazarinova, D.B., Ivanova, V.G. and Taisheva, V.V. (eds.) Epistema dialoga. K 50-letiu professora M.M. Mchedlovoi: sbornik nauchnykh trudov [Epistemic Dialogue. Marking the 50th Jubilee of prof. M.M. Mchedlova: Collected Papers]. Moscow: RUDN, pp. 35-41.

Kazarinova, D.B., 2018. Kholodnaya voina i mir: "Rossia protiv vseh" i chetyre mirovyh poryadka R. Sakvy [The Cold War and Peace: "Russia against All" and R. Sakwa’s Four World Orders]. Polis. Politicheskiye issledovaniya, 4, pp. 177-184.

Kazarinova, D.B., 2016. Obraz budushchego v Rossii: tsennostno-politicheskaya proyektsiya [Russia's Vision of the Future: A Value-Political Projection]. In: Scientific-Practical Conference with International Participation "Management in the Field of Science, Education and Technological Development". Moscow: Moskovsky Politeh, pp. 57-62.

Kharitonova, O.G., 2017. Politicheskiye rezhimy i rezhimnyie izmeneniya v zerkale nauchnogo diskursa [Political Regimes and Regime Change in Scientific Discourse]. Vestnik RUDN. Seriya: POLITOLOGIA, 19 (4), pp. 379-391.

Kondrashev, A.A., 2013. Sovremenny politicheskiy rezhim Rossii: ogranicheniya bazovyh grazhdanskih prav i svobod posredstvom zakonodatel'nyh novatsii i pravoprimenitel'noi praktiki [Modern Political Regime in Russia: Restrictions on Basic Civil Rights and Freedoms by New Legislative Acts and LawEnforcement Practice]. Konstitutsionnoye i munitsipal'noye pravo, 2, pp. 10-17.

Konstantinova, N.S. and Martynov, B.F., 2008. Imidzh Rossii v Brazilii: ukorenivshiyesya stereotipy i faktory optimizatsii [Image of Russia in Brazil: Fixed Stereotypes and Factors of Optimization]. Analiticheskiye tetradi ILA RAN, 20, pp. 88.

Lebedeva, M.M., 2017. "Myagkaya sila": poniatiya i podkhody ["Soft Power": Notions and Approaches]. Vestnik MGIMO Universiteta, 3 (54), pp. 212-223.

Lebedeva, M.M. and Kharkevich, M.V., 2014. "Myagkaya sila” Rossii v razvitii integratsionnykh protsessov na yevraziyskom prostranstve [Russia’s "Soft Power" in the Integration Processes in Eurasia]. Vestnik MGIMO Universiteta, 2 (35), pp. 10-13. 
Levada, 2019. Russians Have Become Friendly Non-Europeans. The Levada Center's Survey. Available at: https://www.levada.ru/2019/09/10/rossiyanestali-druzhelyubnymi-neevropejtsami/

Levitsky, S. and Way, L., 2010 Competitive Authoritarianism: Hybrid Regimes After the Cold War. New York: Cambridge University Press.

Lexed.ru, 2000. Natsional'naya doktrina obrazovaniya v Rossiyskoi Federatsii do 2025 goda [National Conception of Education in the Russian Federation up to 2025]. [online]. Available at: http://www.lexed.ru/obrazovatelnoe-pravo/ knigi/yagofarov2005/413.php [Accessed 01 March 2019].

Mchedlova, M.M., Gavrilov, Yu.A. and Shevchenko, A.G., 2015. Rossiyskaya identichnost': patriotizm, gosudarstvo, religiozno-mirovozzrencheskiy factor [Russian Identity: Patriotism, the State, the Religious Worldview Factor]. Islam $v$ sovremennom mire: vnutrigosudarstvennyy i mezhdunarodno-politicheskiy aspect, 11 (3), pp. 35-48.

Mid.ru, 2016. Kontseptsiya vneshney politiki Rossiyskoy Federatsii ot 30 noyabrya 2016 g. Foreign Policy Concept of the Russian Federation asof November 30, 2016]. Available at: http://www.mid.ru/foreign_policy/news/-/asset_publisher/ cKNonkJE02Bw/content/id/2542248 [Accessed 01 March 2019].

Nye, J., 2009. Soft Power. New York: Public Affairs.

Pantin, V.I. and Lapkin, V.V., 2018. Transformatsia politicheskih prostranstv $\mathrm{v}$ usloviyah perehoda $\mathrm{k}$ politsentrichnomu miroporyadku [Transformation of Political Spaces in Conditions of the Transit towards a Policy-Centric World Order]. Polis. Politicheskiye issledovaniya, 6, pp. 47-66.

Pew Research Center, September 2018. News Use Across Social Media Platforms 2018. [online] Pew Research Center. Available at: http://www.journalism. org/2018/09/10/news-use-across-social-media-platforms-2018/ [Accessed 01 March 2019].

Pew Research Center, December, 2018. Americans Still Prefer Watching to Reading the News - and Mostly Still Through Television. Available at: http:// www.journalism.org/2018/12/03/americans-still-prefer-watching-to-readingthe-news-and-mostly-still-through-television/ [Accessed 01 March 2019].

Pew Research Center, October, 2018. Western Europeans Under 30 View News Media Less Positively, Rely More on Digital Platforms Than Older Adults. Available at: http://www.journalism.org/2018/10/30/western-europeansunder-30-view-news-media-less-positively-rely-more-on-digital-platformsthan-older-adults/ [Accessed 01 March 2019]. 
Ponomareva, Ye.G., 2016. "Myagkaya sila” Rossii kak integratsionny resurs [The "Soft Power" of Russia as an Integration Resource]. Geopolitichesky zhurnal, 3 (15), pp. 9-17.

Portland, 2016. The Soft Power 30. A Global Ranking of Soft Power 2016. [online]. Portland, p. 37. Available at: https://portland-communications.com/ pdf/The-Soft-Power-30-Report-2016.pdf [Accessed 17 February 2019].

Portland, 2017. The Soft Power 30. A Global Ranking of Soft Power 2017. [online]. Portland, p. 41. Available at: https://softpower30.com/wp-content/ uploads/2017/07/The-Soft-Power-30-Report-2017-Web-1.pdf [Accessed 17 February 2019].

Portland, 2018. The Soft Power 30. A Global Ranking of Soft Power 2018. [online]. Portland, p. 43. Available at: https://softpower30.com/wp-content/ uploads/2018/07/The-Soft-Power-30-Report-2018.pdf [Accessed 17 February 2019].

Pravo.gov.ru, 2012. Ukaz Prezidenta $R F$ "O vnesenii izmenenii v Strategiyu gosudarstvennoi natsional'noi politiki Rossiyskoi Federatsii na period do 2025 goda" [Directive of the RF President "On Amendments to the Strategy of the National Policy of the Russian Federation up to 2025"]. [online]. Available at: http://pravo.gov.ru/proxy/ips/?docbody=\&prevDoc=102161949\&backlink=1 \&\&nd=102488842 [Accessed 17 February 2019].

Project 5-100 official web page. Available at: https://www.5top100.ru/ documents/regulations/

Ruskline.ru, 2015. Strany BRIKS gotovy sami nachat' formirovat' pravila mirovogo ustroistva [BRICS Countries Ready to Start Shaping the World Order Rules Themselves]. [online]. Available at: http://ruskline.ru/opp/2015/5/23/ strany_briks_gotovy_sami_nachat_formirovat_pravila_mirovogo_ustrojstva/ [Accessed 01 March 2019].

Russia.edu.ru, 2002. Kontseptsia gosudarstvennoi politiki Rossiyskoi Federatsii $\mathrm{v}$ oblasti podgotovki natsional'nyh kadrov dlya zarubezhnyh stran v rossiyskih obrazovatel'nyh uchrezhdeniyah ot 18 oktyabrya 2002 g. [The Concept the RF State Policy in Training Labor Force for Foreign Countries in Russian Educational Institutions as of October 18, 2002]. [online] Available at: http:// www.russia.edu.ru/information/legal/law/inter/conception/ [Accessed 01 March 2019].

Samofalova, Ye.I., 2015. Osobennosti izucheniya obrazovatel'noi migratsii $\mathrm{v}$ rabotah zarubezhnyh avtorov [The Specifics of Educational Migration 
Research in the Works of Foreign Authors]. Vestnik Tomskogo gosudarstvennogo universiteta. Filosofiya. Sotsiologiya. Politologiya, 1(29), pp. 104-119.

Sakwa, R. and Kazarinova, D.B., 2018. The Radicalization of the West and the Clash of World Orders. An interview with Richard Sakwa. RUDN Journal of Political Science, 20 (2), pp. 148-153.

Skornyakova, S.S., 2012. Politichesky rezhim i yego evolyutsia v sovremennoi Rossii [Political Regime and Its Evolution in Modern Russia]. Sotsiologia $i$ pravo, 2 (13), pp. 37-43.

Tarasov, Ye.F., 2006. Odraz Rossii: metodologiya issledovaniya [Image of Russia: Research Methodology]. Voprosy psiholingvistiki, pp.69-73.

Tishkov, V.A., 2018. Vvedeniye [Introduction]. In: Tishkov, V.A. and Stepanov, V.V. (eds.) Etnicheskoye $i$ religioznoye mnogoobraziye Rossii [Ethnic and Religious Diversity of Russia], 2nd Edition. Moscow: IEA RAN, pp. 5-11.

Volkov, D. and Goncharov, S., 2018. Predstavleniya o budushchem u molodezhi krupnyh gorodov v Rossii, Ukrainze i Belarusi. Opros "Levada-tsentra" [Young People's Vision of the Future in Russia, Ukraine and Belarus. Survey of the Levada Center]. [online]. Available at: http://zukunftsbild.nemtsovfund.org/ survey-ru/ [Accessed 1 March 2019].

Voronkov, L.S., 2015. Mezhdunarodnye organizatsii: osnovnye prichiny ih vozniknoveniya i razvitiya [International Organizations: Basic Reasons for Their Emergence and Development]. Vestnik MGIMO Universiteta, 4 (43), p. 102-110.

Zircon.ru, 2019. Izmerenie stepeni tsennostnoi solidarizatsii $i$ urovnya obshchestvennogo doveriya $v$ rossiiskom obshchestve [Assessment of the Degree of Value-Based Solidarity and Social Trust in Russian Society]. [online]. Available at: http://www.zircon.ru/upload/iblock/d20/Doverie_i_cennostnaja_ solidarizacija_Prezentacija.pdf [Accessed 2 April 2019].

Zubov, A., 2011. The Perception of Russian Culture and Its Role in Shaping Russia's Image Abroad. Valdai Club Papers. [online]. Available at: http:// valdaiclub.com/a/highlights/the_perception_of_russian_culture_and_its_ role_in_forming_russia_s_image_abroad/ 